
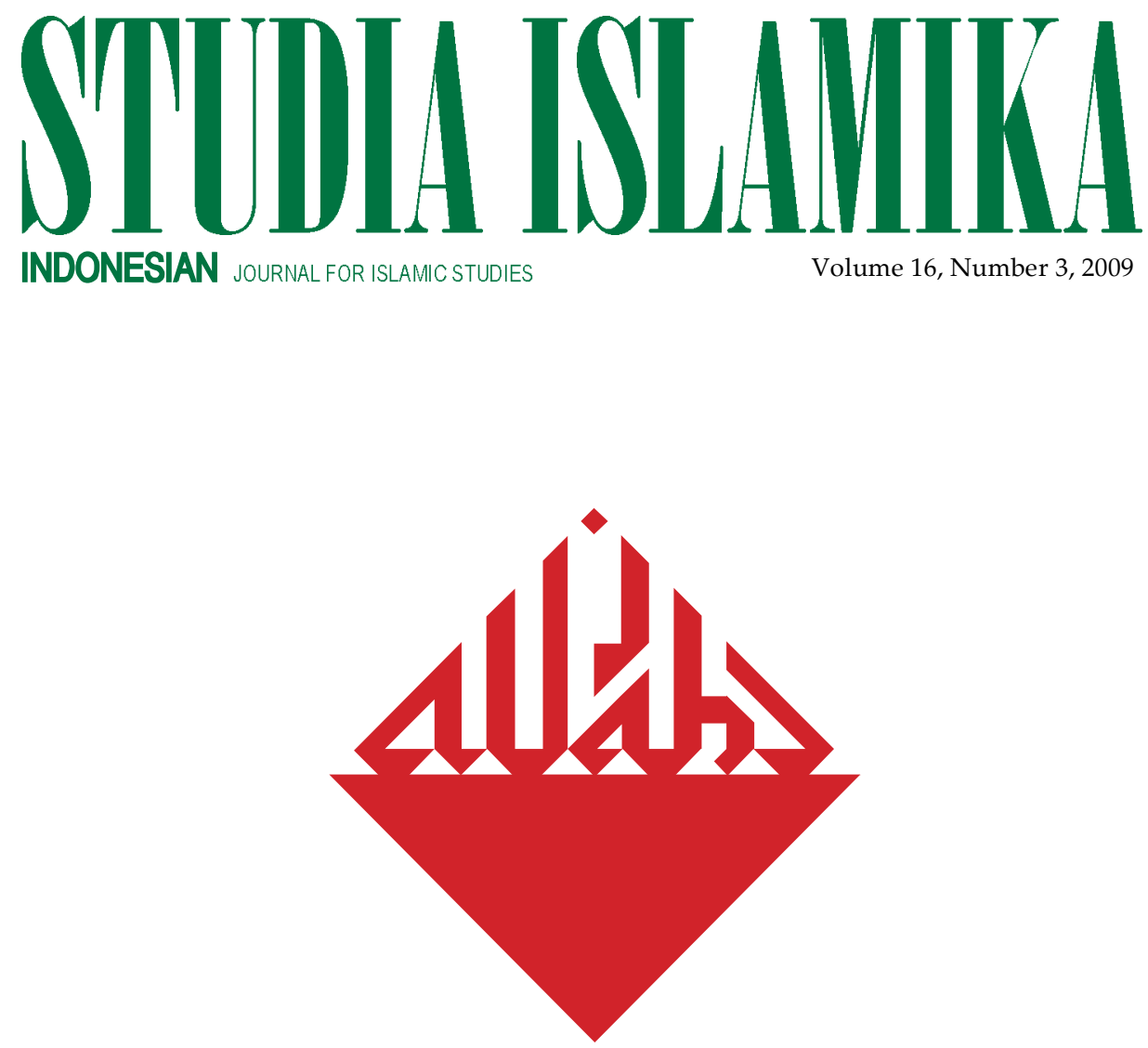

The Payung and the Rising Sun:

A Study of Javanese Pangreh Praja

DURING THE JAPANESE OCCUPATION I 942-I 945

Bahtiar Effendy

DisRupting Spatiality and Temporality:

Authority and Statecraft in HiKaYAT MARESKALEK

Ismail F. Alatas

Islamist Civil Society Activism in Malaysia under Abdullah Badawi: The Angkatan Belia Islam Malaysia (ABIM) and the Darul Arqam Ahmad Fauzi Abdul Hamid 


\section{STIDIIA ISLAMIIKK}

Indonesian Joumal for Islamic Studies

Vol. 16, no. 3, 2009

\section{EDITORIAL BOARD:}

M. Quraish Shihab (UIN Jakarta)

Taufik Abdullah (LIPI Jakarta)

Nur A. Fadhil Lubis (IAIN Sumatra Utara)

M.C. Ricklefs (National University of Singapore)

Martin van Bruinessen (Utrecht University)

John R. Bowen (Washington University, St. Louis)

M. Atho Mudzhar (UIN Jakarta)

M. Kamal Hasan (International Islamic University, Kuala Lumpur)

M. Bary Hooker (Australian National University, Australia)

Virginia Matheson Hooker (Australian National University, Australia)

\section{EDITOR-IN-CHIEF}

Azyumardi Azra

\section{EDITORS}

Jajat Burhanudin

Saiful Mujani

Jamhari

Fiad Jabali

Oman Fathurahman

\section{ASSISTANT TO THE EDITORS}

Setyadi Sulaiman

Testriono

\section{ENGLISH LANGUAGE ADVISOR}

Dick van der Meij

\section{ARABIC LANGUAGE ADVISOR \\ Nursamad}

\section{COVER DESIGNER}

\section{S. Prinka}

STUDIA ISLAMIKA (ISSN 0215-0492) is a journal published by the Center for the Study of Islam and Society (PPIM) UIN Syarif Hidayatullah, Jakarta (STT DEPPEN No. 129/SKIDITJENIPPG/ STT/1976). It specializes in Indonesian Islamic studies in particular, and South-east Asian Islamic Studies in general, and is intended to communicate original researches and current issues on the subject. This journal warmly welcomes contributions from scholars of related disciplines.

All articles published do not necessarily represent the views of the journal, or other institutions to which it is affiliated. They are solely the views of the authors. The articles contained in this journal have been refereed by the Board of Editors.

STUDIA ISLAMIKA has been accredited by The Ministry of National Education, Republic of Indonesia as an academic journal (SK Dirjen Dikti No. 83/Dikti/Kep/2009). 


\title{
Southeast Asia and the Middle East: Islam, Movement, and the Longue Durée
}

\author{
Kevin W. Fogg
}

(Eric Tagliacozzo, ed. Stanford, CA: Stanford University Press, working with NUS Press in Singapore, 2009). viii+392 pages.

Abstrak: Hubungan historis Asia Tenggara dan Timur Tengah pada tujuh sampai delapan abad lampau diakui sangat penting. Namun, karya-karya kesarjanaan tentang dialog panjang antara dua peradaban tersebut relatif masih kurang. Buku yang diedit Eric Tagliacozzo ini mengisi kekurangan tersebut.

Buku ini memuat sejumlah karangan yang membahas hubungan regional Asia Tenggara dan Timur Tengah selama lebih dari satu milenium. Penambahan kata longue duree pada subjudulnya—sebuah istilah dari mazhab sejarah struktural Annales di Prancis_bermakna kecenderungan-kecenderungan dan kekuatan-kekuatan yang berperan dalam menciptakan hubungan tersebut. Kerangka longue duree ini digunakan dalam pengertian jangka waktu yang panjang, bermula dengan kedatangan Islam sampai pada masa kini. Untuk memudahkan pembaca dan agar lebih sistematis, buku ini disusun ke dalam empat bagian: Early Dimensions of Contact, Colonial Age, First Half of the $20^{\text {th }}$ Century, dan Into Modernity.

Bagian pertama diawali oleh artikel Michael Francis Laffan tentang evolusi nama-nama geografis berbahasa Arab di Asia Tenggara. Artikel ini masuk ke dalam pembahasan yang detail, yang boleh jadi cukup sulit dipahami oleh para pembaca yang tidak memiliki latar belakang pengetahuan sejarah memadai. Artikel berikutnya ditulis Timothy Barnard yang mengangkat pembahasan tentang pengalaman haji elite Bugis, beserta makna politik dan budaya dari perjalanan itu. Sementara Mohammad Rezuan Ahmad mengangkat perdebatan tentang siapa dan bagaimana Islam masuk ke Asia Tenggara, dengan kesimpulan bahwa orang-orang Arab telah mengislamisasikan Asia Tenggara.

Memasuki pembahasan tentang masa kolonial, terdapat artikel M. C. Ricklefs yang mendiskusikan tentang pembaruan keagamaan dengan menguji statistik dari masa kolonial Belanda. Berdasarkan data itu, Ricklefs membedakan dua tipe 
kepemimpinan agama di Jawa selama abad ke-19: pemimpin agama tradisional yang terlibat dengan aktivitas Belanda dan pemimpin yang belajar di Timur Tengah yang berkonsentrasi di wilayah pesisir utara Jawa. Eric Tagliacozzo, editor buku ini, menyumbang artikel yang menyoroti kebijakan haji kolonial Belanda berdasarkan laporan-laporan yang ditulis oleh Snouck Hurgronje. Artikel berikutnya ditulis oleh Sumit K. Mandal, yang mengangkat pembahasan tentang masyarakat Arab di Jawa pada masa kolonial. Sementara Nico Kaptein mencoba mengungkap perdebatan seputar isu-isu modernitas dan identitas yang dikemukakan oleh penduduk pribumi Asia Tenggara.

Bagian ketiga buku ini, yang membahas tentang paroh pertama abad ke-20, dimulai artikel Michael Gilsenan yang memfokuskan pada orang-orang Arab di Asia Tenggara sebagai "diaspora" (daripada sebagai etnis minoritas), dan memahami pembagian kepemilikan sebagai bagian dari penyebaran mereka di wilayah tersebut. Sementara Ulrike Freitag mencoba memperkenalkan sebuah dokumen primer berupa surat, beserta analisisnya, yang dikirim oleh seorang ayah Arab kepada anak dan keponakan laki-lakinya ketika mereka memulai kariernya di Asia Tenggara. Sementara Mona Abaza menulis seorang Indonesia-Arab yang menjadi tokoh internasional terkemuka bernama M. Asad Shahab.

Dalam bab terakhir, yang membahas tentang Asia Tenggara dalam kurun modern, John Sidel mengetengahkan suatu pembahasan tentang motivasi gerakan kaum ekstrimis di Indonesia dan Filipina, dimulai dari periode kolonial di kedua negara tersebut. Sementara Moshe Yegar mengangkat perspektif historis komparatif, dengan mengkaji tiga gerakan pemberontakan di Asia Tenggara (Birma, Thailand, dan Filipina), dengan melihat persamaan dan perbedaan ketiga gerakan tersebut. Artikel terakhir ditulis oleh Syafi'i Anwar yang memetakan kelompok-kelompok Islam di Indonesia kontemporer ke dalam dua tipologi: Islam konservatif-radikal dan Islam liberal-progresif.

Buku ini merupakan karya yang penting bagi para sarjana yang meminati isu-isu tentang pengaruh Timur Tengah di Asia Tenggara. Meski demikian, ada catatan penting untuk buku ini, yakni tidak meletakkan kedua wilayah yang dibahasnya pada kedudukan yang seimbang. Hampir semua artikel menempatkan Timur Tengah pada posisi khusus terutama dalam kaitan pengaruhnya pada masyarakat Asia Tenggara. Terlepas dari itu, buku ini tetap sangat membantu bagi studi-studi mengenai hubungan Asia Tenggara dan Timur Tengah di masa depan. 


\section{Book Review}

\section{Southeast Asia and the Middle East:}

\section{Islam, Movement, and the Longue Durée}

Kevin W. Fogg

(Eric Tagliacozzo, ed. Stanford, CA: Stanford University Press, working with NUS Press in Singapore, 2009). viii+392 pages.

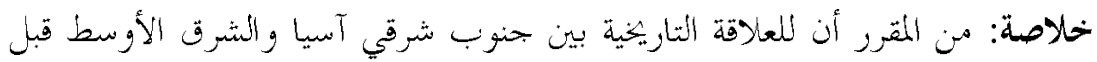

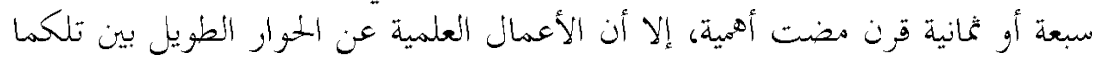

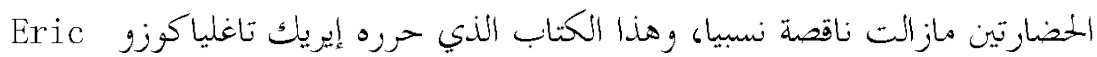
Tag1iacozzo

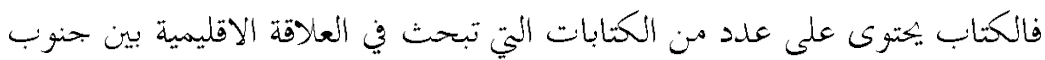

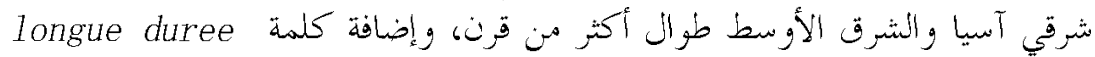

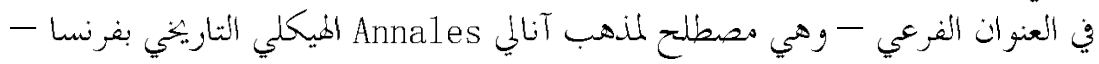

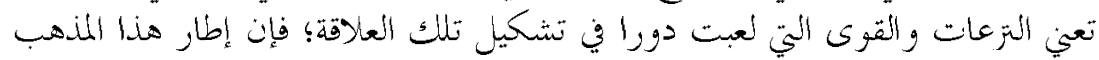

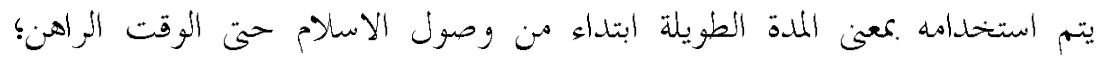

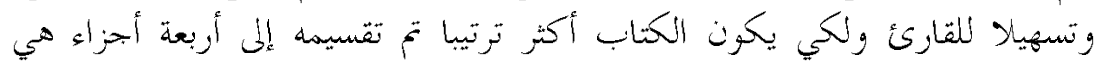

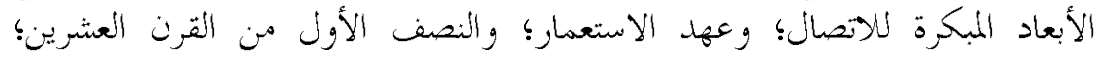

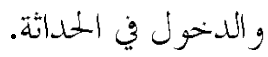

ويبدأ المزي الأول ممقال كتبه ميكائل فرانسيس لابان Laffan

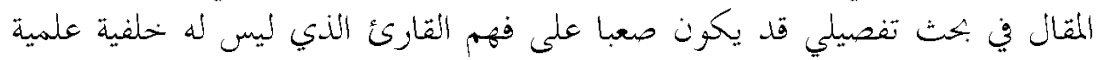

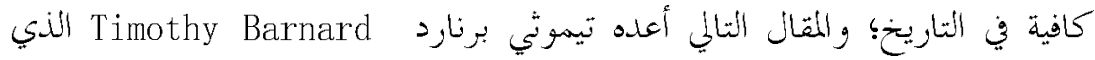

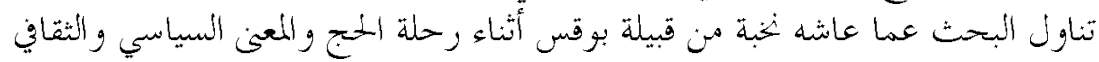

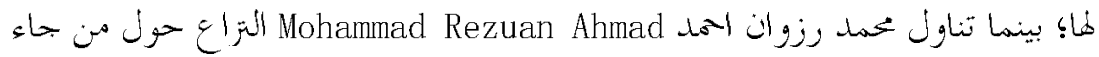

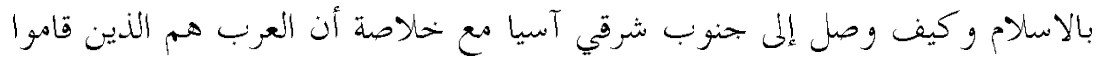

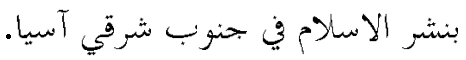




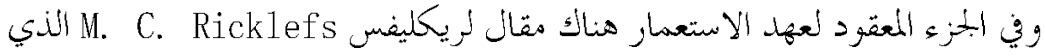

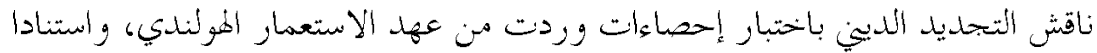

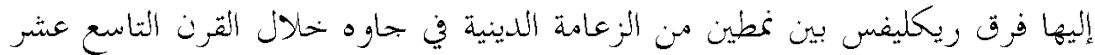

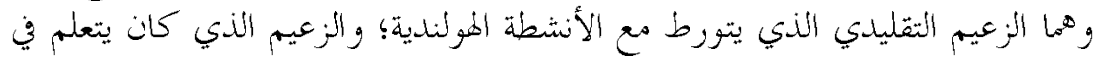

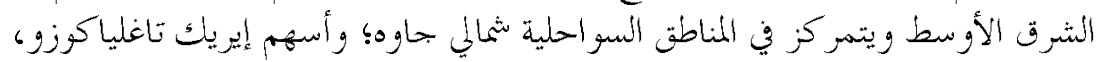

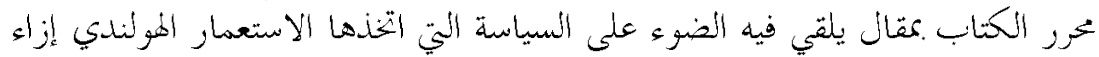

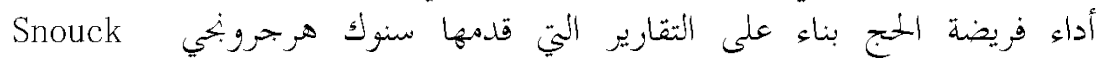
بurgronje

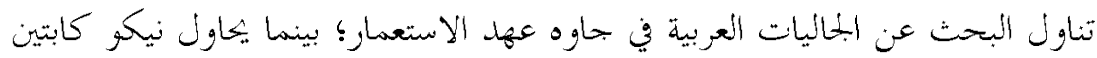
Nico Kaptein عرضها سكان جنوب شرقي آسيا الأصليين.

يبحث المزيء الثالث من الكتاب في النصف الثابي من القرن العشرين مبتدئا بالمقال

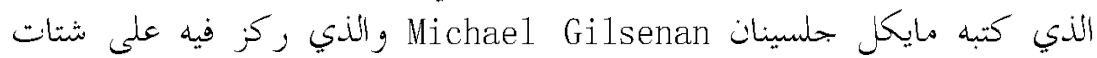

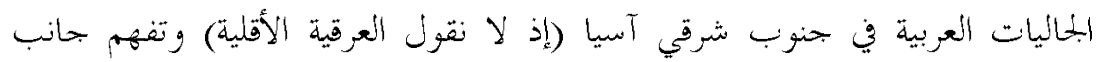

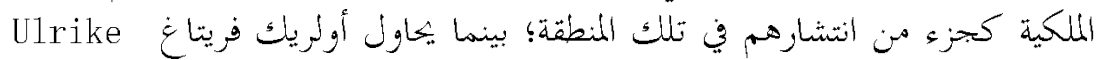

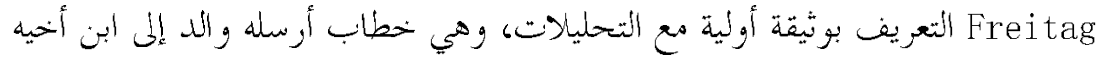
عندما بدأ عمله في حنوب شرقي آسيا، بينما تكتب مني مني أباظه

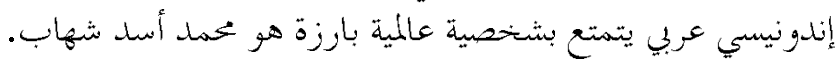

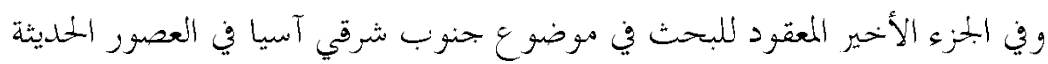

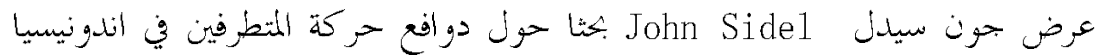

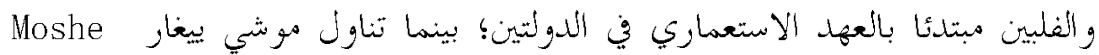

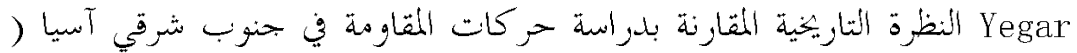

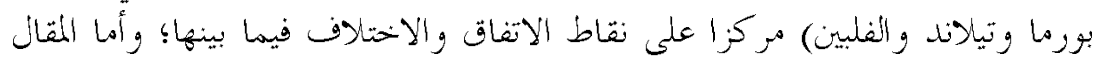

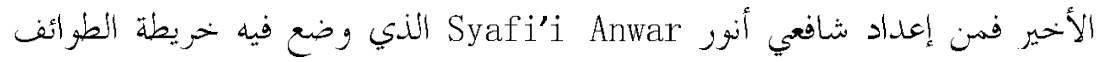

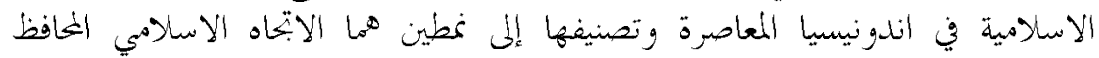

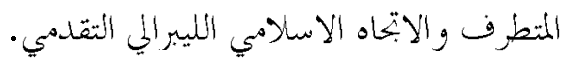

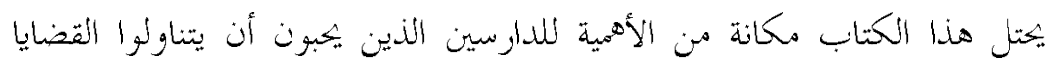

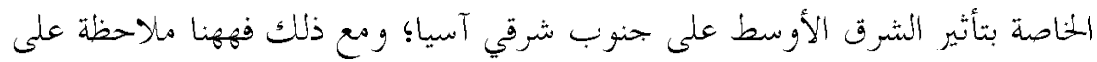

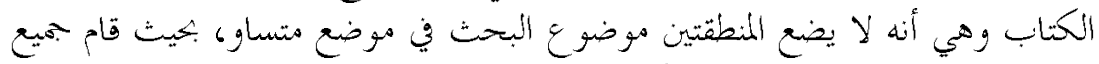

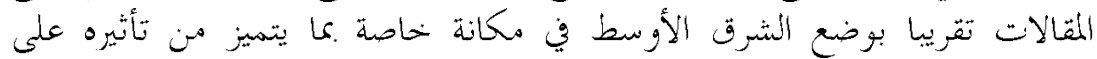

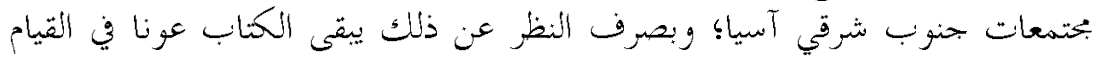

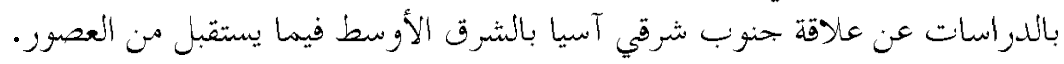


I $\mathrm{n}$ his introduction to this volume, Eric Tagliacozzo, a historian at Cornell University, USA, is very right to say that "the ties between Southeast Asia and the Middle East have ... been extremely important in the past seven to eight centuries," and that the scholarly community lacks "a volume on what the parameters of this long-distance dialogue between civilizations have meant over the centuries." (1) This book has brought together scholars from around the world to begin to fill this gaping hole. Especially with regards to the influence of the Middle East on Southeast Asian (Muslim) society, the various articles add significantly to our understanding.

The book also aspires to go beyond a limited, brief, local perspective by bringing together essays from over a millennium of inter-regional connections. The appendage of longue durée to the subtitle, invocative of the Annales school of structural history emerging out of France several decades ago, indicates a focus to broader trends and forces at work shaping the relationship. The immediate effect of this longue durée framework is seen, though, in the broad range of time periods addressed in the volume, beginning with the dawn of Islam and running through the present.

In order to organize such a great span of history, the book is divided chronologically into four sections: Early Dimensions of Contact, Colonial Age, First Half of the $20^{\text {th }}$ Century, and Into Modernity.

\section{Early Dimensions of Contact}

The first article of the volume comes from Michael Francis Laffan, a historian at Princeton University, USA. Previously known for his work on the colonial period, this article reaches much further back to study the evolution of geographic names in Arabic for island Southeast Asia. The title is "Finding Java: Muslim Nomenclature of Insular Southeast Asia from Śrîvijaya to Snouck Hurgronje." The article goes into great detail, and is not easily accessible for those without some background knowledge of the geography and languages at play.

Laffan reads through the classical Arab geographers to look at the changing of names over time, both in using a new word and in a word being used referring to a new place. Building from the common term Zâbaj, through the transitional identification Qamar, Laffan finally arrives at the use of the term Jâwa/ Jâwî, which is the real destination of the essay. Concerning this last term, Laffan finds that "more than 
being a term for the undoubted hybridity of the people of maritime Southeast Asian ports, Jâwî was both a pan-ethnic ascription used by Arabic-speaking outsiders cognizant of the importance of Java in the 13th and 14th centuries, and (increasingly) an Islamic cultural one for insiders." (43) Another interesting narrative of this change in names, though, is how they reflect changes in the trading or cultural center of Southeast Asia, from the coast of Cambodia and the Straits of Melaka to a more inclusive picture with a prominent place for the island of Java.

Following on this essay, Timothy Barnard presents a more focused study entitled "The Hajj, Islam and Power among the Bugis in Early Colonial Riau." Barnard, based at the National University of Singapore, uses a variety of sources, including contemporary manuscripts by Malays and the famous book on Mecca by Snouck Hurgronje, to provide insight into the hajj journey of Raja Ahmad in 1828. Barnard does a good job of not only recounting for readers the experience of the hajj, but also the cultural and political importance of this journey for the Buginese elite. As outsiders controlling the Riau archipelago at a time of threatening colonial expansion, participation in the hajj allowed Buginese to employ a new justification for their presence in the Straits: religion.

Mohammad Rezuan Ahmad combines historiographical and historical goals in his study, "The Origins and Contributions of Early Arabs in Malaya." Despite the title of the article, Ahmad includes concerns from as early as the founding of Islam and as late as World War II, focusing on the question of who brought Islam to Southeast Asia and how. He gives a very useful, succinct summary on pages 87-88 of the Orientalist and Western tradition of scholarship which believes Indian traders initiated the Islamization of the region; this summary makes the article very useful for those just getting to know the scholarship on Islamization. Ahmad attempts to add to this scholarship and take it in a new direction by relying on Malay local traditions and references to Southeast Asia in Arab geographies, which lead him to conclude that it was Arabs (not South Asians) who Islamized Southeast Asia.

One has to wonder, though, whether this conclusion is a neutral evaluation of the sources available. Certain statements in the article, such as an assertion that prior to the Portuguese there was a "Arab monopoly over regional trade, which had never really been seriously 
challenged before," (86) totally ignoring the role of South Asians, East Asians, and indigenous traders themselves, lead one to think that the author is single-mindedly writing an Arab genealogy for Southeast Asian Islam, rather than neutrally evaluating the available evidence. Most disappointingly, Ahmad never considers the distinct possibility that local traditions could have invented an Arab origin for their Islam so as to try and bolster their religious authority—a very real possibility. Ahmad searches diligently for the shrimp behind the rock when Orientalists identify South Asia as the source of Islamization; it would be appropriate that he apply the same scrutiny to traditional Malay sources. Overall, this article has a noble goal of bringing local knowledge back into the history of Islamization, but a very weak execution of this mission.

\section{The Colonial Age}

As the volume moves into the colonial period, it adds a third region into the study: the distant colonial metropolis of Europe. Although the focus of the book remains on connections between the Middle East and Southeast Asia, Europeans now appear as facilitators, hurdles, and foils of those connections.

In his article "The Middle East Connection and Reform and Revival Movements among the Putihan in 19th Century Java," National University of Singapore historian M. C. Ricklefs brings new insights regarding religious reform by examining key statistics from the colonial era. Some of this material overlaps with the content of his 2007 book Polarizing Javanese Society. Using Dutch records of hajjis by district, Ricklefs is able to distinguish two distinct types of religious leadership on Java during the nineteenth century: traditional religious leaders who were more complicit with Dutch activity and Middle Eastern-trained leaders who concentrated on the north coast (Pasisir) region of Java.

This demographic and geographic difference begins to explain some religious phenomena of the nineteenth century, like the religious reform of coastal areas and the regions of conflict between sufi-aligned religious leaders and Middle Eastern-influenced ones obsessed with orthodoxy rather than tradition. Although many forces were coming to play on Javanese religious life, Ricklefs identifies reform and revival movements from the Middle East as having "a decisive role in stimulating change in religious circles." (130) One of the great virtues of this article is that 
it comfortably recognizes Dutch power on Java at the time (such as it was), without overemphasizing their influence or overstating their role. Ricklefs does very effectively, though, employ Dutch statistics and sources to reach his detailed conclusions about social forces.

The editor of the volume, Eric Tagliacozzo, himself contributes an interesting article to the volume by adding to the already significant literature about the prominent Orientalist and Dutch colonial official C. Snouck Hurgronje. In the article, "The Skeptic's Eye: Snouck Hurgronje and the Politics of Pilgrimage from the Indies," Tagliacozzo works through the private reports Snouck Hurgronje sent back to his Dutch colonial superiors to examine all the information on hajjis, the Middle East, and hajj policy. By focusing on these more private documents, Tagliacozzo is able to color with more detail an aspect of Snouck's personality already apparent from his famous book on Mecca: "Snouck loved the Middle East, and he particularly loved to study the connections between the Hejaz and 'his own' Netherlands Indies." (148) The impact on the hajj policy was, however, rather ambivalent. Snouck feared or hated certain aspects of the effects on returning Indies natives just as much as he respected and treasured the Muslim Holy Lands and a center for scholastic and religious activity. Because of this duality, Tagliacozzo concludes that Snouck left an "ambiguous legacy at best." (149)

Although Tagliacozzo is very well-read in the literature on this topic, both primary and secondary, this particular essay is slightly disappointing in two ways. The first is the non-committal conclusion of "ambiguity" in the policy and practice Snouck Hurgronje recommended. This leaves the reader feeling more informed but still directionless at the end of the essay. The second criticism, in this particular context, is that this article is not properly about the Middle East nor Southeast Asia; it is instead about a European man's relationship with both regions and, at its heart, about the European man himself. So, while interesting, this essay does not help our understanding of the dynamics of Southeast Asia- Middle East relations. Nevertheless, Tagliacozzo paints a detailed and engaging picture of the colonial side of the early twentieth century in insular Southeast Asia. In this it connects very well with the two subsequent essays.

Sumit K. Mandal of Universiti Kebangsaan Malaysia writes a piece on Arabs in Java in the same time period, and he (or his subjects) note 
many of the same trends that Snouck Hurgronje saw. This is an essay that brings the book properly into the national period, as evidenced in the title: "Challenging Inequality in a Modern Islamic Idiom: Social Ferment amongst Arabs in Early 20th-century Java." Questions of identity and loyalty, especially as a member of a community of privilege, connect well with Tagliacozzo's discussion of Snouck Hurgronje. The "Modern Islamic Idiom" here is the multi-ethnic Muslim society and the new, more egalitarian, modernist theology seeping through the Islamic world at that time. Mandal looks very closely at the work of Soerkati and the organizations like al-Irsyad that attacked traditional Hadrami privilege, hierarchy, and exclusivity. The effects, mostly in Javanese society at the birth of the nationalist movement but also echoed in the Hadramaut (this is mentioned but not explored), were damaging for the position of Arabs in Southeast Asia, eventually bringing them closer to the position of indigenous Muslims. The traditional Arab leadership on Java fought hard against these changes, but without lasting success.

To close this section, another article on the same time period, "Southeast Asian Debates and Middle Eastern Inspiration: European Dress in Minangkabau at the beginning of the 20th Century," looks at similar issues of modernity and identity through indigenous Southeast Asian eyes. This article is incredibly focused, perhaps the least fitting in the volume with the longue durée idea, but it is tight, well-argued, and very interesting. Nico Kaptein, a researcher at Leiden University in the Netherlands, examines the rhetoric and actions of the famous kaum muda ulama of the early twentieth century in Sumatera Barat. Of course their relationship with the issue of authority was different from that of the kaum tua, but so also was their relationship with the Middle East. They traced themselves to a different intellectual genealogy, and they sought different Middle Eastern authorities to support their theological (and praxical) positions. While the kaum tua sent off to Mecca for a series of fatwa on issues of dress, the kaum muda wrote in to Rashid Rida's al-Manar and disseminated their ideas in similar papers in the archipelago. In sum, Kaptein uses the issue of clothing as an informative case study, highlighting how identity (in both local and global contexts) was changing during those tumultuous decades. 


\section{The First Half of the Twentieth Century}

Michael Gilsenan adds to the volume by taking a very different perspective on the popular question of Arabs in Southeast Asia: keeping Arab families together economically. The essay starts with a welcome examination of historiographical issues surrounding the study of Arab families in Southeast Asia (families, as opposed to individuals), but throughout balances the personal level with an economic perspective that seems very appropriate for the subjects at hand: major trading families. Perhaps because Professor Gilsenan's background is as a Professor of Middle East Studies at New York University in the US, he focuses on Arabs in Southeast Asia truly as a diaspora (rather than just an ethnic minority), and understands the division of property as part of their spreading out in the region.

This article, "History of Arab Families and Inheritance in Southeast Asia," hopes to set up the terms for a more extensive future study of his title subject. Thus, he spends the first half of the article briefly outlining issues like Arab families, diaspora, legal systems and property. In the second half of the article, he applies these ideas in two case studies of legal disputes in Singapore. The arguments presented, both about issues of inheritance between family members and a family collective, show the conflict between Arab, English (the colonial power) and local legal traditions, as well as the conflict between individuals. This article is, just as Gilsenan hopes, a very promising foundation for future studies.

Ulrike Freitag's contribution connects very well to Michael Gilsenan's article. Freitag, a professor of Islamic studies at Free University in Berlin, Germany, is unique in providing both analysis and a primary document for the reader (in the original Arabic and in translation). As the title of her article, "From Golden Youth in Arabia to Business Leaders in Singapore: Instructions of a Hadrami Patriarch," suggests, this is a letter that was sent by an Arab father to his son and nephew when they were headed out to start their careers in Southeast Asia. It is a great find as a document, and it shows the sorts of concerns and priorities held by Arab traders in the region. These include the potential network that the young men will build, promising business prospects, and even homesickness. Other resources like this one should be made widely available for researchers to access and benefit from.

Mona Abaza, a sociologist at the American University of Cairo, Egypt, rounds out the section with a study of an Arab Indonesian 
individual who became a prominent international figure, entitled "M. Asad Shahab: A Portrait of an Indonesian Hadrami who Bridged Two Worlds." Sayyid Mohammad Asad Allah bin Ali bin Ahmad bin Abdallah bin al-Hussayn bin Shahab al-Din (whom she very familiarly calls SMAS) was born in Indonesia in 1910, entered journalism in the 1930s, and then left Indonesia for self-exile in Saudi Arabia and Europe in 1965, living abroad until his death in 2001. Living abroad did not mean he was no longer involved in Southeast Asia; his visit to and writings on the Muslim question in the southern Philippines was an important influence on Arab thought about that issue. In addition to his book on the Moro question, Abaza examines thoroughly his unique perspective in the book Sefahat min tarikh Andunisia al-mu'assira (Pages from Contemporary Indonesian History) and one of his peculiar novels, Mim samim al-waqe, also known as An Indonesian Novel which Has No Female Character. This essay provides context for these works and for this man's life, explaining his tendencies of anti-communism and opposition to Soekarno. The reader also learns about several interesting episodes surrounding modern Middle Eastern Salafism and Southeast Asia.

\section{Into Modernity}

The question of Salafism and its modern influence comes up again in John Sidel's breath-taking article "Jihad and the Specter of Transnational Islam in Contemporary Southeast Asia: A Comparative Historical Perspective." In my opinion, this is far and away the best article in the book. Sidel, a political scientist at the London School of Economics and Political Science, UK, starts by reviewing the current literature on Southeast Asian extremism and terrorism, insightfully identifying the faults of both fear-mongering faux academic works and very detailed but narrow think-tank studies. He then tries to transcend and re-order the field by looking at the motivations of extremist movements in both Indonesia and the Philippines over a longer historical period, beginning from the colonial period in both countries.

In looking back historically, Sidel provides exactly the sort of structural, longue durée revelations that this volume hopes to put forward. This perspective allows him to see the movements' motivations, roots and organizations, rather than just their short-term modus operandi. In the Philippines, Sidel charts the various consequences of the position 
of Muslims as a minority population; in Indonesia, the issue is the exclusion of Islam (and, often, Muslims) from politics and power in different ways throughout modern history. In both cases, Sidel documents very well the broader project that Islamist organizations hope to undertake, one of "unifying Muslims divided by political conspiracies, particularistic practices, and parochial interests and understandings." (311) He also finds (in a way that would stun most of the authors he reviews initially) that "jihad in Southeast Asia is, as elsewhere in the Muslim world, overwhelmingly reactive and defensive in nature." (312) While those other works have purpose and are often, especially in the case of think-tank studies, innovative and necessary, this article by John Sidel is just the correction that the broader field of "terrorist studies" in Southeast Asia needed.

The following article, by Moshe Yegar, also gives a comparative historical perspective. This essay, entitled "Some Comparative Notes on Three Muslim Rebellion Movements in Southeast Asia (Burma, Thailand, and the Philippines)," looks at the similarities and differences of the three movements in Southeast Asia. The major findings of this former professor at Hebrew University, Jerusalem, are not always easy to find, because the article is not very well-organized. However, there is a lot of information available, and this is in some ways a very useful summary of Yegar's larger book on the subject: Between Integration and Succession: The Muslim Communities of the Southern Philippines, Southern Thailand and Western Burmal Myanmar. Those who are less familiar with these movements should start with the book, because some background information is not clear in the article, but it does become quickly observable that Yegar believes the level of activity and success of the movements is in relation to their size and organization, less in their location or the nature of the state they oppose. This should be balanced with the author's rather pessimistic position on the future of these communities in their respective countries: "Because of their ideological outlook and because they will not adapt to non-Muslim rule, Muslim populations in Southeast Asia are unable to be absorbed into the majority culture." (346)

The final essay of the book is "Political Islam in Post-Suharto Indonesia: The Contest between 'Radical-Conservative Islam' and 'Progressive-Liberal Islam',' by M. Syafi'i Anwar, an NGO leader from the International Center for Islam and Pluralism in Jakarta. Anwar 
plainly outlines the main theological groups coalescing in Indonesia; no longer is Muslim society split harshly between traditionalist and modernist but now more between what he terms radical-conservatives and progressive-liberals. Part of the article is meticulously documenting the positions of these two camps on a variety of issues, from gender to pluralism to politics. For those just beginning to study contemporary Muslim society in Indonesia, this could be a good introduction. However, the article clearly was not updated since the 2004 conference, which makes it behind on many of the political and social developments since that time. The division between RCI and PLI is also rather simplistic, and Anwar should recognize more diversity within each of these groups and also identify individuals who sit in between them.

\section{The Volume as a Whole}

This book is well worth examining, especially for those interested in the influence of the Middle East in insular Southeast Asia. The essays are generally well-written and insightful. There are, however, a few directions in which this scholarship needs to expand.

First, the book stops short of tackling head-on the structures driving the relationship between Southeast Asia and the Middle East and the key moments of structural change. While the book is certainly longue durée in the most basic sense of an extended time period, it lacks a summarizing essay or unity between the articles that could help it to achieve something more analogous to Annales-style history.

Secondly, and more disappointingly, this book does not put the two regions on equal footing. None of the essays (with the possible exception of Mona Abaza's) locates itself primarily in the Middle East. None of the essays looks at Middle East society and the impacts that Southeast Asia have made thereto. This is unfortunate in several ways. One is that it misses a number of juicy research topics that could easily have been included, such as the use of Southeast Asian products in the Middle East, the impact that Middle Eastern peoples brought back to their homeland after journeys in Southeast Asia, the scholarly communities of Southeast Asians residing in key Arab cities (not merely after their return - several of the essays deal with that) and now the modern phenomenon of Southeast Asian domestic workers and hard laborers in cities on the Arabian peninsula. A more serious problem is that this sort of unequal analysis can also suggest to readers, scholars and students that 
the regions have (or worse yet, should have) an unequal relationship, with the Middle East emanating ideas and individuals which Southeast Asia has but to receive. I have no delusions that the participants at the 2004 conference nor the writers for this volume actually believe that to be the nature of Southeast Asia- Middle East connections; I merely want to point out that scholarship should be more balanced, or even directly challenge such a perspective, which is apparent in the writings of Snouck Hurgronje and the perceptions of many Southeast Asians today. More balance in the ways the zones are treated would more properly demonstrate the "dialogue" that Tagliacozzo cites. (1)

Finally, it is unfortunate that the organizers were unable to find scholars connecting the Middle East with more than Muslim Southeast Asia. Although the insertion of "Islam" into the subtitle might exempt the book from this goal, the picture of Middle East- Southeast Asia relations would have been more complete with the inclusion of information on the Persians in Thailand, Armenian community in Singapore, or Christian Southeast Asians now undertaking pilgrimages to the holy sites of Israel/ Palestine. Such alternative topics are lost in a sea of articles about the Arab diaspora in Muslim Southeast Asia.

These points, however, do not detract in the least from the strength of the individual essays in this collection, nor do they refute the great addition to the field of Southeast Asia- Middle East studies that this volume provides. I join with Prof. Tagliacozzo in hoping that this book "will help point the way," (10) for many future studies on the myriad connections between the two regions.

Kevin W. Fogg, PhD. student at Yale University, USA 